\title{
Transformation Form in Banua Layuk Mamasa Based on Linguistic Analogy
}

\author{
Wasilah $^{1}$, Andi Hildayanti ${ }^{2}$ \\ ${ }^{1,2}$ Departement of Architecture, Faculty of Science and Technology, \\ Universitas Islam Negeri Alauddin Makassar, Indonesia. 92113 \\ \{wasilah@uin-alauddin.ac.id ${ }^{1}$, andi.hildayanti@uin-alauddin.ac.id²
}

\begin{abstract}
Aim of this research is to interpret the architectural meaning in Banua Layuk Mamasa based on linguistic analogy. This traditional architecture is closely related to the philosophy or meaning either in form or ornament of the building. This research practice phenomenological analysis method with theoretical approach. Therefore, architecture linguistic study in Banua Layuk is according to three interpretation model, grammatical model, expressionist, and semiotic model. Architectural knowledge with philosophy and meaning in Banua Layuk house would become a comprehensive learning media for the next generation. The result explained that the Banua Layuk Mamasa form is determined by topography and climate condition considerations. Form transformational phase practiced with trial and error method to acquire a perfect form. Banua Layuk have a capability to create a harmony with nature, nondestructive and adopt the environmental condition, and integration that creates a harmony. Banua Layuk form transformation relates on the philosophy and life principles of Mamasa society, reflects on the Banua Layuk elements, such as the building form, rooms organization, and element that creates a space.
\end{abstract}

Keywords: Architectural, Linguistic Analogy, Building Form, Traditional Houses, Banua Layuk.

\section{Introduction}

All social aspect in Mamasa traditional society are always determined by the customs and traditions. This customs and traditions become a guideline in act and thinking in accordance with the pattern of the society life. The customs and traditions reflect in behavior, way of interaction, includes in a practice in house development inside their environmental. The customs and traditions and belief are the forefather's heritage, fills the heritage core. These becomes a belief and heritage that directly accepted from the Regulator of Cosmos to guides the practice of social institutions.

According to Budiharjo, traditional architecture strongly emphasizes in the process of form, based on ritual, religion or belief. In fact, the physical form becomes the last priority[1]. The symbolic value is always becoming an integration part from the traditional works. Symbol would be understanding based on the interpretation context of the culture, with culture specific characteristic. Keraf in Rohidi explained the symbol as a medium to store or express the 
meanings, either in form of ideas, attitudes, judgments, longings, or believe, and also as an abstraction from fixed experience in understandable form [2].

One of the traditional architecture forms is traditional house or vernacular house. There is a traditional house and popular with "Banua" in Mamasa District, West Sulawesi Province. The form tends to Tongkonan house in Toraja. The house cosmology produces a basic form of "Banua" in form of rectangle. Universe as a cosmos determined into three worlds:

1. Upper Banua or Langi' as the upper world, light, and good. [3]

2. Middle Banua or Lino or padang, a field for man to perform their activity, especially an offering and worship ceremony.

3. Lower Banua, a place of deata-deata, the underwater world caretaker, identified as servant and bad.[4]

The word "banua" means house, "layuk" means height, and "banua layuk" means a stilt house or elevated house with big size and high. Most of the owner is the leader of a society or nobility. Banua Layuk (Figure 1) is a traditional house, bigger and higher than another Banua. Banua Layuk has five or six rooms and the resident is from Tana' Bulawan class. [5][6]

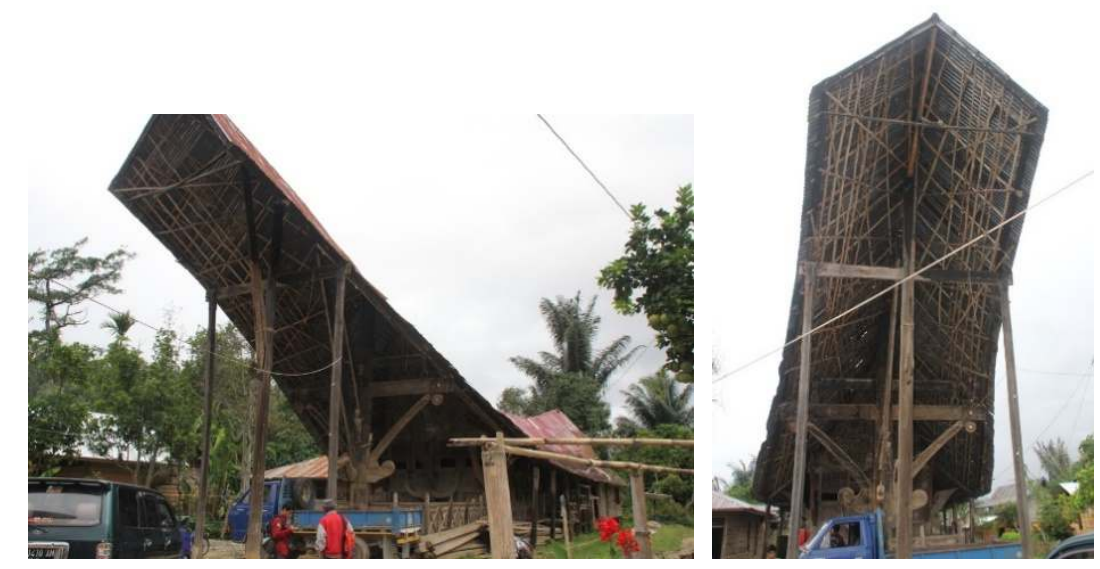

Fig. 1. Banua Layuk Mamasa

Banua Layuk Mamasa achieved an architectural transformation. This modification is a result of building adoption to the local natural condition, such as climate, wild animal threat, and etc. [7] The most significant form transformation appears in the roof of Banua. The roof is different with the Toraja vernacular building or Tongkonan. Banua Layuk angle roof is slopeer than Tongkonan roof. However, the roof form is slightly different. The roof length in the front and back area of the building is different. The form transformation of Banua Layuk Mamasa will discuss below.

\section{Material and Methods}

The observation object is Banua Layuk Mamasa, located in Orobua and Tawalian Village. The object is one of traditional architecture in Indonesia that consistently preserve until nowadays. Data collections are in form of object documentation and local information through interview method. The data analyses by phenomenology method, in order to interpreting the 
form meaning [8] of Banua Layuk Mamasa. The analysis method applies theoretical approach, architecture linguistic analogy which assumed that the building will delivering an information to the observer with one of these three method [9]:

a. Grammatical Model

Architecture considered has elements (words), organized with rule (grammatical and syntax) that creates a possibility for the society in specific culture understand rightly and interpret the intention of the building. This condition would achieve if the "language" is public language that truly understand by people (langue).

b. Expressionist Model

The building considers as a medium for the architect to express his/her attitude to the building project. In this case, the architect implements his/her personal "language" (parole). His/her language probably understand by other people or not.

c. Semiotic Model

Semiology is a study of signs. The semiotic interpretation of architecture stated that a building is a sign of information delivery, what is all about and what is the function. The building with piano form would be a piano store. A tower in the building would become a building of a church.

This research interprets the grammatical, expressionist, and semiotic model structured in Banua Layuk Mamasa based on the building form transformation.

\section{Results and Discussion}

Banua Layuk orientation is to the north and facing to Tanete Karua, a Mountain with Eight Water Springs. Tanete Karua is one of sacred mountain and believe as a source of life. Consequently, the meaning is related to the God immanency for the agriculture society, the Nature [10] or in this event is the mountain, Tanete Karua. Banua Layuk is the place for sacred activity and closely practice in a family, all activity must center and oriented to the God, The Creator and The Fountain of Life

The development of Mamasa vernacular house architecture has four processes or phases, which are:

1. Banua Pendoko Dena (the house form is like a sparrow nest; the form is not completely rounded; the material is from local environment such as grass, leaves, bamboo, and timber; the floor is soil).

2. Banua Lantang Aqpa (house with rectangle form; four walls from bamboo or log that directly planted into the ground; wall and roof are from bamboo, timber, and grass; today, there would be Mamasa but the function has become a barn).

3. Banua Tamben (the wood of this house is alternately in all sides; no pile, except the ridge to organize the roof; at first the roof is from thatch material, then some of roofs are from bamboo).

4. Banua Toloq. Toloq 'tusuk' (present form; banua toloq means all piles have a hole, then connected by pattoloq; banua toloq form is like a sail boat).

Presently, traditional house in Mamasa is a development result from previous form, initiated from banua pandoko dena, banua lentong appa, banua tamben and banua tolo' (sanda ariri). As a result, the fourth house form (banua tolo) became the traditional house characteristic feature, especially Banua Layuk in Mamasa that depend to location, orientation, and building material, and period to build the house.

Banua Layuk consists of three structures, roof, rooms, and basement. The roof is a symbol of upper world, rooms is a symbol of middle world, and basement is an under world symbol. 
The house is a description of macrocosms in vertical perspective. House building is a complete existence that known in agriculture society [10][11].

Vertically, Banua Layuk Mamasa is an elevated house that constituted by three parts, which are:

1. The house roof or papa' Banua is a sacred zone, an upper world symbol, place of the Gods and ancestor spirit. The roof form is pitching and the size is increasing to the top as a The Creator greatness realization. The Mamasa traditional house has heavy wood roof and curved slightly. The roof form is broad, adopted with a high rainfall in Mamasa.

2. The house body or kalu Banua is a symbol of middle world, a residence place for the owner activity, includes floor and wall.

3. The basement or illi' Banua is a symbol of under world/a mortality place. This area is a residence place for creature/animal. The basement in Banua Longkarrin is not equipment by fence, thus the place would not become as an animal space.

Table 1. Transformation Phase in Banua Layuk Mamasa Roof

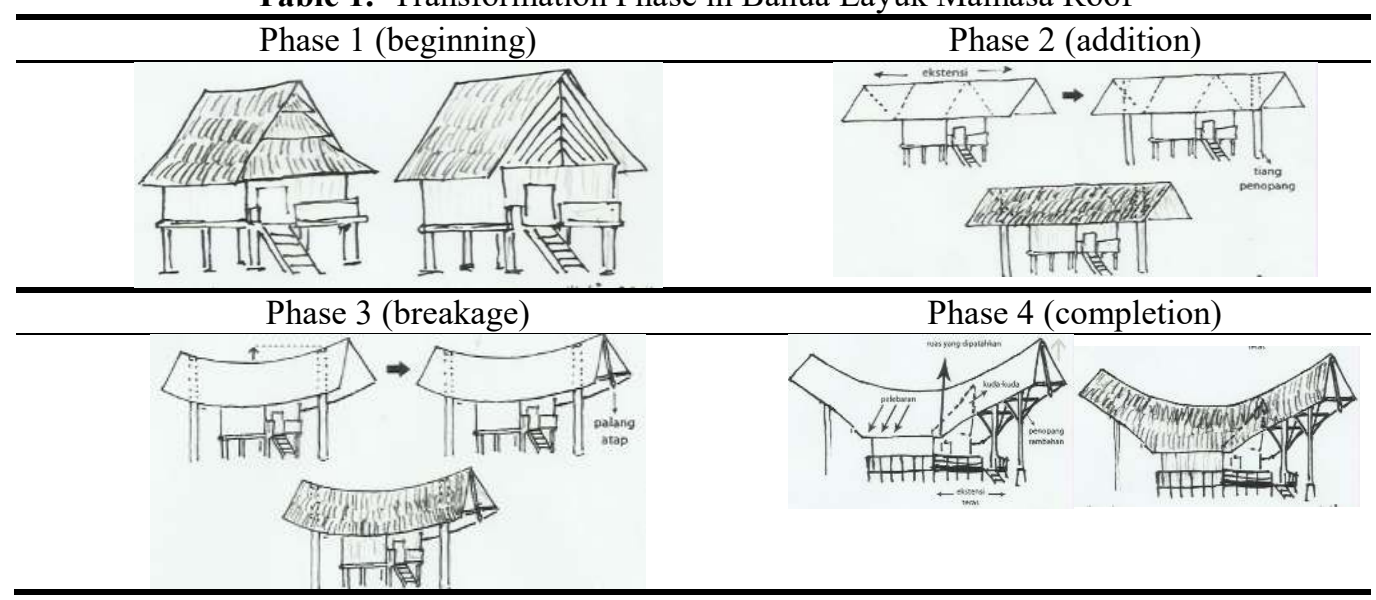

According to linguistic architecture analogy theory, Banua Layuk Mamasa interpretation are:

\subsection{Grammatical Model}

According to Unwin the first element in architecture is the basic elements that are not consider as an object, but also as an element that present place and space [12]. Examples of these basic elements are ground area (lowered or elevated), marker, focus, barrier, roof, path, and openings. Implementation basic architecture elements in Banua Mamasa are:

a. A lowered ground area is a place for animal house or barn, then elevated into a terrace or Sali-sali.

b. Maker is the primary coloumn in Banua Layuk Mamasa or calls as Penulak. The function is to support the building or Longa.

c. Focus element in architecture as the spotlight in Banua Layuk Mamasa is BadongBadong.

d. Barrier in Banua Layuk Mamasa calls as Rinding, separates between one place with another place. 
e. Roof in Banua Layuk Mamasa calls as Papa Banua. The function is to protect from rain and a symbol of protector.

f. Path in Banua Layuk Mamasa is a ladder or Eran.

g. Openings in Banua Layuk Mamasa are in form of door and window.

Visual form in Mamasa traditional house presents a symbol of unity in harmony, vertically or horizontally. The visual form and description of architectural components in Banua Layuk Mamasa are as follows (figure 2):

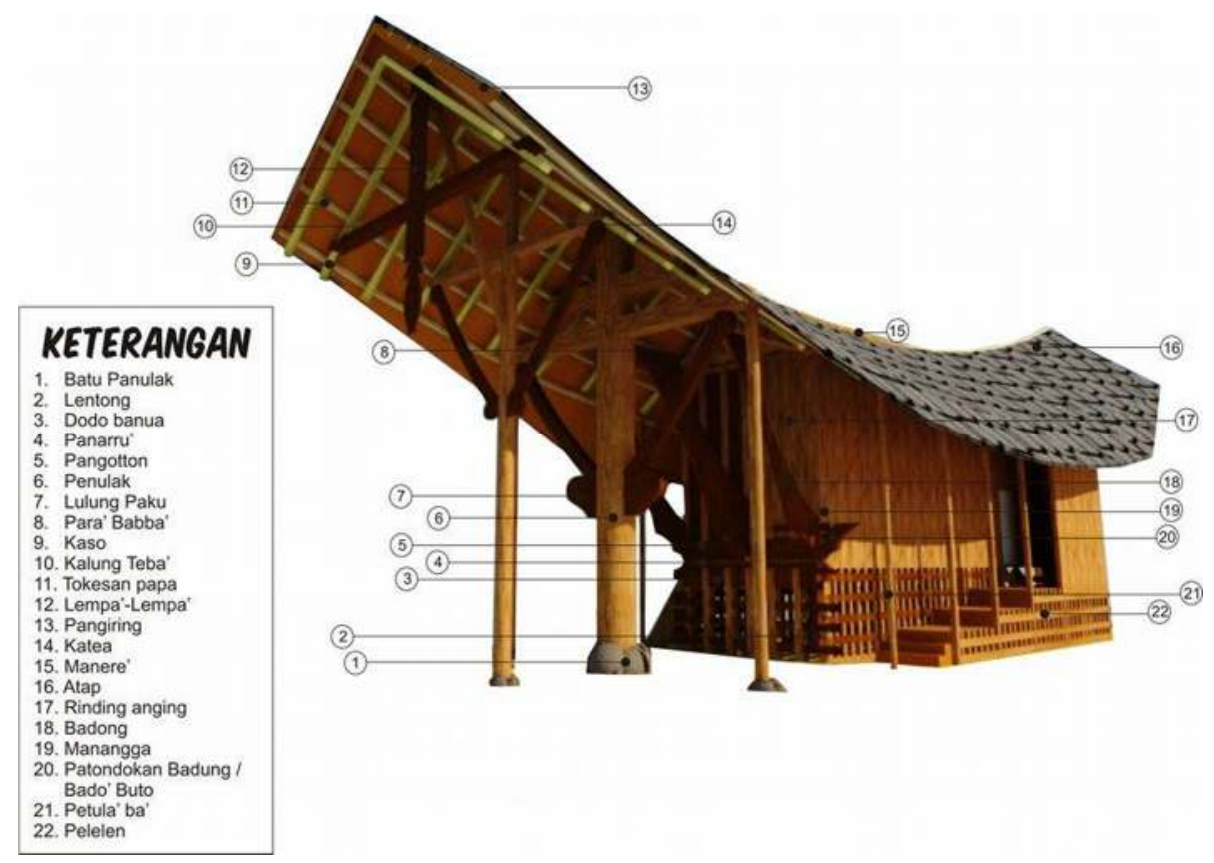

Fig. 2. Components of Banua Layuk Building Structure

\subsection{Expressionist Model}

According to the long history, the early of Banua Layuk architecture is three plane area, like the Bugis and Makassar house. Because of an increasing in population in family member and economy, the idea to extend the roof length arise. The front and back roof side, as supported by Ching theory in Additive Form [13]. An extended roof to outward has a pile (support) to support the roof being falling. During the house roof phase with upward curved and according to indepth interview from the author to the chief of the custom society in Mamasa Regency, there are two possibilities reason for an extended house roof in Banua architecture. The first reason is because accidental factor. The support pillar is higher than roof pile and the house roof becomes curved rather than becomes flat roof. This reason in accordance with support pile availability from the tree trunk. The second reason is intentional factor. There is a reason to arise the house roof vertically with longer support piles from the roof to achieve maximum view, better illumination to make the terrace becomes brightly [14]. Considering to small size in window and door. 
In order to gain a completeness level from roof of Banua Layuk Mamasa architecture, after arising the roof, roof segment in left-right edge modified (breakage). The left-right segment widened. The yard part shrinking forward. The truss is lengthwise and inclining to forward to support the roof. The supporting pillar strengthen by yard area, two supporting pillars equipped by crossbar with additional support in left-right side of the front area. Consequently, the veranda becomes longer following the roof and the back roof becomes stabilization.

Moreover, application of linear organization in the space has a relationship with Mamasa society daily activity who works in agriculture field. The farmer has multiple mentality characteristics, consumptive-productive, connection based on a strong relationship. In term of building structure, there are three patterns in space categorization and hierarchy structure. Dualism concept is clearly observer, a contradiction element must unite with medio in the middle part. For example, room partition positioning is lengthwise in the center area from southern to the north in order to differentiated the honorable guest chair position in west side and the householder member in east side.

One-way circulation applied for all Banua (slightly similar), crossing Tambing room is forbidden (the most sacred room inside the house). When someone enter the house from the front door, then the exit door must be the front door too. When someone enter the house from the front door then leaving from the back door or otherwise, Mamasa society believe the fortune would be passing by anyway and will not reside inside the house. For family or relative, they must be understood that they will enter from kitchen or lombon, the quest will enter from tado' in front door.

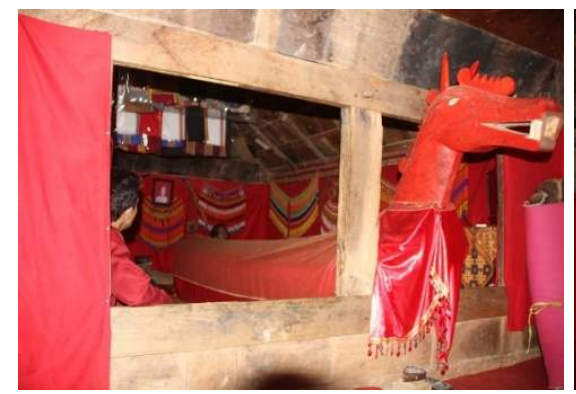

Fig. 3. Banua Layuk atmosphere

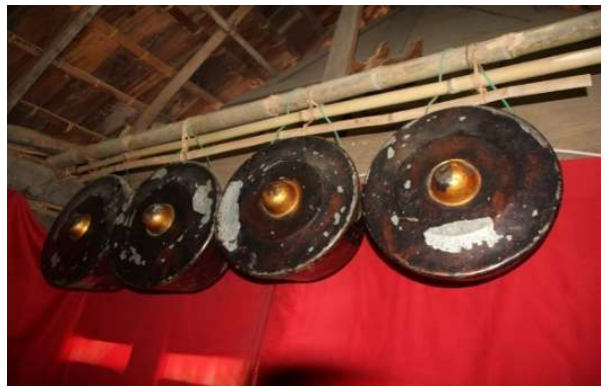

ayuk atmosphere

The atmosphere of Banua Layuk dominated by red color (figure 3), a human blood symbol and a symbol of human life. Mamasa society believe that a death in young people would become an adult and the death in old people will return into a young people. Therefore, they would not worry about the death. The floor pattern combines horizontal and vertical structure, indicates a three pattern structures, an opposite couple and one part in the middle area.

Long ago, pata' (a spreading room partition, long and vertically) applied as a partition for welcome guest according to social stratification. The left side is for lower class and the right side for the upper middle-class guest. Today, most building floor has no timber material application. In this Banua, the floor covered by vinyl with wood theme or wood theme ceramic. There is a floor leveling $\pm 50 \mathrm{~cm}$ from Ba'ba to Tambing area, differentiated the sacred room and profan/upper-lower course that known in three pattern society.

Banua Layuk plafond has an open ceiling, the roof frame clearly observed and the light is ray, enter through plafond slot (Figure 4). Plafond exposes the roof frame, explaining a truthfulness meaning that should be built in the family. The plafond will be covered with yellow cloth during the event/traditional ritual ceremony. The yellow color is symbol of purity [15][16], there is a relationship to the sungai kuning philosophy that known by Mamasa society. Composition of yellow, red, and black are a symbol of upper, middle, and under world. 

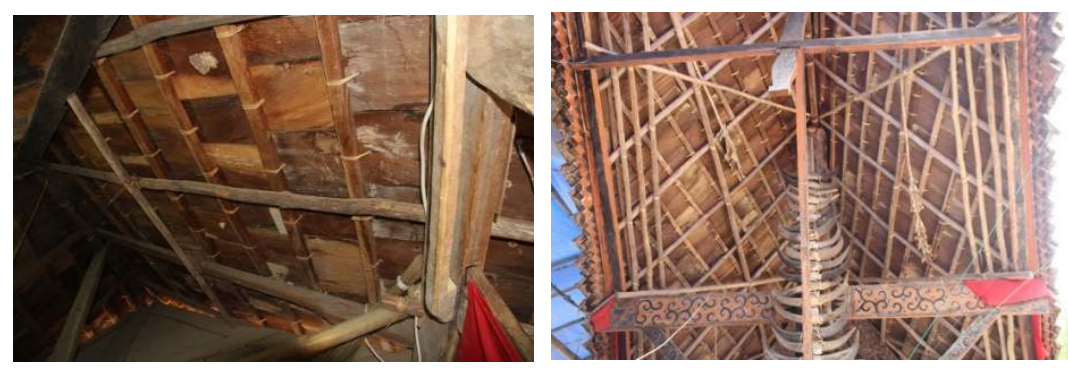

Fig. 4. Open Ceiling in Banua Layuk Roof Frame

\subsection{Semiotic Model}

Banua Layuk building appears in symmetrical form and balance between the left and right side. Forms application in this building are geometry in integrated of form structure of Banua, either in construction part or the ornament. Moreover, balance principle observes in pairing parts and connected each other. The Banua Layuk roof material is from plaited $u r u^{\prime}$ wood and culminate to the top forward to the northward or Tanete Karua. The roof form is alike a ship. This form has a relationship with the history of Mamasa society ancestor. More culminate to forward is a symbol of a greatness of The Creator [17]. A dominant roof proportion in Banua is a symbol, roof is the guardian, "an open sky" is shading the householder (figure 5).

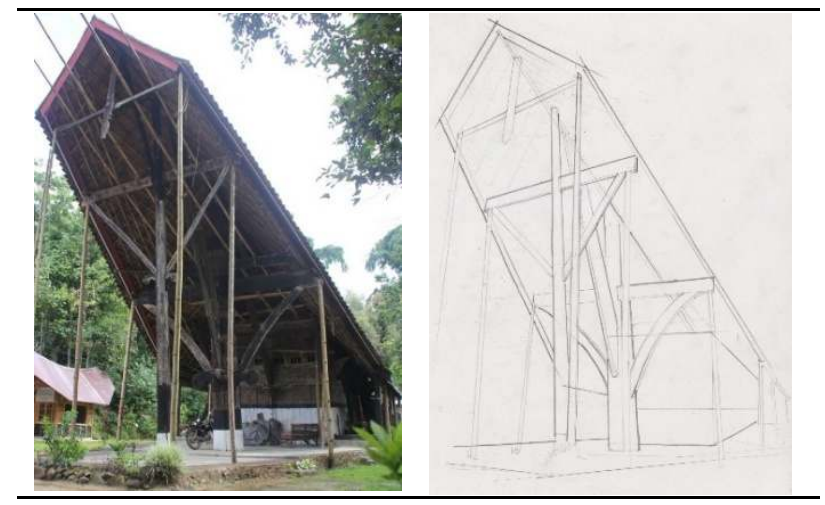

Fig. 5. Banua Layuk Roof Form

Banua Layuk body starts with Timbak Layuk. Timbak Layuk positioning is in uppermost of house body with roof pitch is $\pm 60^{\circ}$. Timbak Layuk is the foundation of Mamasa traditional house. Timbak Layuk positioning is in front area of the house to the inner part and decorated with carving, Barana. Timbak Layuk form relates to the three pattern structures, a symbol of mountain. The meaning is Axis Mundi, the dualism connection between sky and earth and the connection of Under World and Upper World. Isosceles triangle form in Timbak Layuk with vertical and horizontal line in the middle area is the meaning of connection between God and man must have good relationship. Timbak Layuk is a connector and decorated with carving, Barana, a symbol of society guardian. There are two ficus trees or Ficus benjamina. The tree 
becomes the most sacred tree in Mamasa society and consider as the sacred place for worship to the Gods.

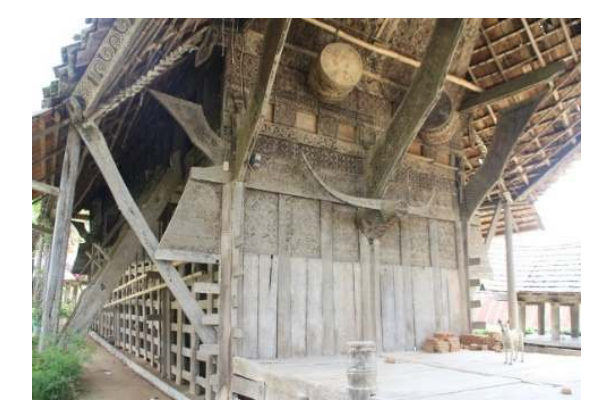

Fig. 6. Buffalo horn ornament in the front part of Banua Layuk

Buffalo head or Tedong put in the front part of Banua Layuk, related to the Mamasa society opinion that buffalo has an important role in their daily life, be sides as dominant cattle (figure 6). Buffalo is a symbol of stratification of a family, assign as prosperity meaning. There are two buffaloes head in Banua Layuk, the male buffalo head in Penulak and female buffalo head in the house body (kale). Both of these buffalo heads are a symbol of couple, man and woman. The symbol meaning is creating a family should consist of a couple, a unity of man and woman. Man as the head of family contributes for its environment (society) and the woman manages the household. This interpretation presents in the positioning of the male buffalo head in front part and the female buffalo head is in back part of the house. According to hierarchy status in household, the head of the family has an important role, the family leader, thus the male buffalo head positioning is in front house.

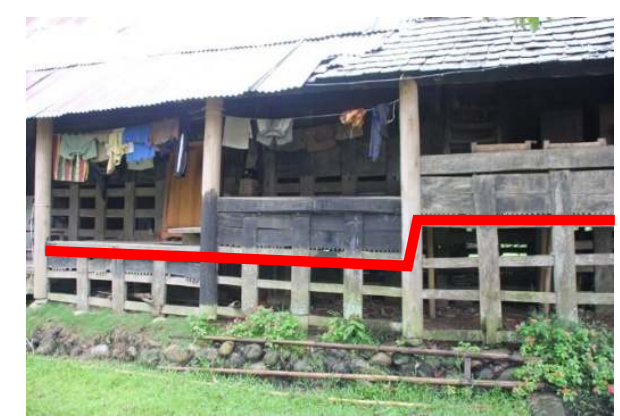

Fig. 7. Construction structure in Banua Layuk is in form of interlocking construction

The space underneath of the house or basement is a place to store the cattle, such as buffalo (tedong) or pig. Banua Layuk construction structure is interlocking each other (figure 7), explaining an integrity in the society through communal activity or gotong-royong that highly respect in Mamasa society. Banua Layuk has no cement foundation, such as modern house, but 
the foundation base supported by big and hard stone, put in every side that creates Banua resistance to the shock.

\section{Conclusion}

Banua Layuk experience in form transformation phases to achieve an ideal form in order to counter the natural condition and local climate. Banua Layuk form transformation relates on the philosophy and life principles of Mamasa society, reflects on the Banua Layuk elements, such as the building form, rooms organization, and element that creates a space. All parts in Mamasa traditional house should not interpret from current context, but required an understanding on the Mamasa society daily life from the past time. Overall, the building form of Banua Layuk has symmetrical pattern, a balance between the left and right side as a related to the three pattern of agriculture pattern that strongly consider on coherence in all aspect of dualism but harmony. This coherence is from an integrity of harmony, between sky and earth, upper world and under world, inside and outside, front and back, east and west. All of this aspect creates a harmony between microcosms (human aspect) and macrocosms (universe).

\section{Acknowledgements}

We thank our colleagues from Orobua and Tawalian village heads, Mamasa community who provided insight and expertise that greatly assisted the research.

\section{References}

[1] Budihardjo, Eko.: Arsitektur sebagai Warisan Budaya [Architecture as Cultural Heritage]. Djambatan. Jakarta. (1997)

[2] Rohidi, Tjetjep Rohendi.: Kesenian Dalam Pendekatan Kebudayaan [Art in a Cultural Approach]. Accent Grafhic Communication. STISI Press. Bandung. (2000)

[3] Wasilah, W., A Hildayanti.: Filosofi Penataan Ruang Spasial Vertikal Pada Rumah Tradisional Saoraja Lapinceng Kabupaten Barru [Philosophy of Vertical Spatial Spatial Planning in Saoraja Lapinceng Traditional Houses, Barru Regency]. pp. 70-79. doi: 10.21776/ub.ruas.2016.014.02.7 (2016)

[4] Wasilah, W.: The Structural Effectivity of Bent Piles in Ammatoan Vernacular Houses. Buildings. Vol. 9, pp.42. MDPI Academic Open Access Publishing. doi:10.3390/buildings9020042 (2019)

[5] Mandadung, Arianus.: Mamasa Dalam Lintasan Sejarah, Budaya, dan Pariwisata [Mamasa in the Journey of History, Culture, and Tourism]. Makassar. (1999)

[6] Government of Mamasa Regency Library and Local Archive.: Hukum Adat \& Pemali Apparandanna Kabupaten Mamasa [Custom Law \& Pemali Apparandanna Mamasa Regency]. Mamasa. (2013)

[7] Waterson, R.: The Living House: An Anthropology of Architecture in South-East Asia.Singapore/Oxford/New York: Oxford University Press. (1990)

[8] Endraswara, Suwardi.: Metode, Teori, Teknik Penelitian Kebudayaan [Method, Theory, and Technique in Cultural Research]. Kanisius Publisher. Yogyakarta. (2006)

[9] Chaer, Abdul.: Linguistik Umum [Typical Linguistic]. Rineka Cipta. Jakarta. (2003)

[10] Sumardjo, Jakob.: Estetika Paradoks [Paradox Aesthetics]. Sunan Ambu Press. Bandung. (2006) 
[11] Mattulada.: Penerapan Unsur Tradisional Kedalam Bangunan Baru [Application of Traditional Element into the New Building]. Seminar Nasional Kebudayaan dan Arsitektur, UGM, Yogyakarta. (1992)

[12] Unwin, Simon.: Analysing Architecture. Routledge. London. (2003)

[13] Ching, FDK.: Architecture: Form, Space, and Order. Van Nostrand Reinhold Company, Inc. USA. (1979)

[14] Wasilah, W.: Natural Illuminance Level of the Expansion House in Suburban Housing Area of Makassar City. Vol. 7, pp.249-251. International Journal of Engineering and Technology. doi: 10.14419/ijet.v7i3.4.19855 (2018)

[15] Ricoeur, Paul.: Filsafat Wacana: Membelah Makna dalam Anatomi Bahasa [Discourse Philosophy: Meaning Exploration in Language Anatomy]. IRCiSoD. Yogyakarta. (2003)

[16] Sumaryono.E.: Hermeneutik sebuah Metode Filsafat [Hermeneutic a Philosophy Method]. Kanisius Publisher. Yogyakarta. (1999)

[17] Ruskin, J.: Tradition and Architecture. University Press. Manchester. (1992) 